\title{
Disputas 2
}

\section{Dr. Alexander Mathiessen ved Institutt for klinisk medisin forsvarte sin avhandling for graden phi- losophiae doctor (ph.d.) 17.01.2018.}

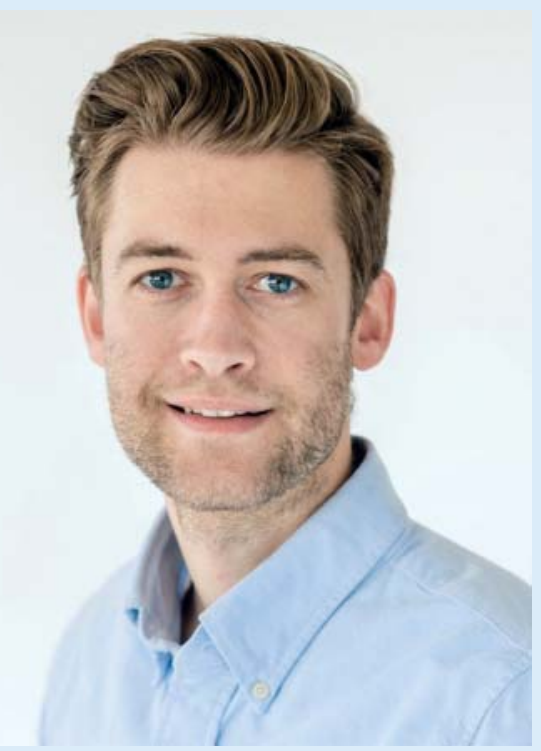

Dr. Alexander Mathiessen

\section{Avhandlingens tittel:}

"Ultrasound of hand osteoarthritis: Validity, reliability and predictive value of ultrasonography in patients with hand osteoarthritis."

\section{Sammendrag:}

Artrose er den vanligste leddsykdommen som spesielt rammer eldre, og som kjennetegnes av smerte, stivhet og funksjonsproblemer. Sykdommen kan oppstå i hvilket som helst ledd, men hånden er den aller mest utsatte. I sin avhandling har Alexander Mathiessen og medarbeidere gjort ultralydundersøkelser av personer med håndartrose ved Diakonhjemmet sykehus.

De fant at ultralyd var like bra som MR og mer følsom enn røntgen i å oppdage artrose. Ultralyd kunne skille mellom frisk og syk brusk, selv i små fingerledd. De fant også at leddbetennelse forekom hyppig i ledd med artrose, noe røntgen ikke er i stand til å fange opp. En leddbetennelsen (synovial hypertrofi og effusjon samt

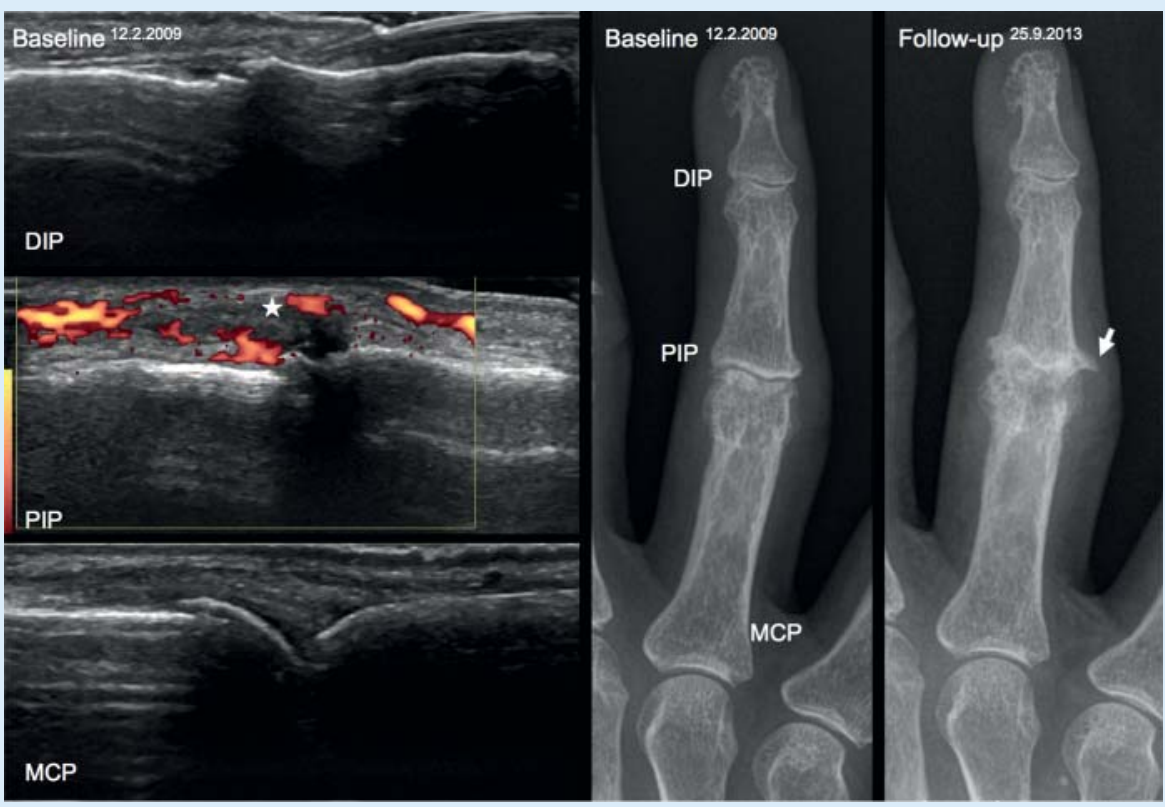

Ultralyd ved «baseline» viste inflammasjon i PIP-leddet (GS synovitt grad 3, PD grad 2). Normalt MCP- og DIP-ledd. I det korresponderende røntgenbildet sees en uttalt forverring av artrose $\mathrm{i}$ PIP-leddet ved «follow-up» fem år senere.

Doppler aktivitet) predikerte progresjon av artrose i det samme ledd over fem år.

"Dette kan potensielt bedre diagnostikken og oppfølgingen av disse pasientene, samt øke vår forståelse av sykdomsprosessene", sier Mathiessen.

Vi vet at ikke bare brusk og ben er involvert i utviklingen av artrose, men at også betennelse i leddene er en driver for sykdommen. Med moderne bildemodaliteter som ultralyd, som både kan undersøke ben og bløtvev, er det ikke lenger like åpenbart hvilken metode man skal bruke for å undersøke artrose. Det er ikke alltid samsvar mellom forandringer som ses på røntgen og pasientens symptomer, og røntgen er ikke i stand til å vise sykdomsforandringer tidlig i forløpet, ei heller bløtdelsforandringer.
"I vanlig klinisk praksis vil nok røntgen fortsatt være bildemodaliteten som supplerer en klinisk undersøkelse av artrose, men ultralyd tilbyr en mer komplett undersøkelse av et ledd, og gjør det mulig å studere både brusken, benete forandringer og leddbetennelse", sier Mathiessen.

For å gjøre metoden bedre har forskerne også utviklet et bildeatlas som kan brukes av leger i ultralyd-diagnostikk av håndartrose.

De som vil lese hele avhandlingen kan finne den i DUO Vitenarkiv:

https://www.duo.uio.no/handle/10852/ 59632 